\title{
SENGKETA TANAH KAWASAN HUTAN DAN RESOLUSINYA DALAM PERSPEKTIF FIQH
}

\author{
Abu Rokhmad \\ IAIN Walisongo Semarang \\ e-mail: abu_rokhmad@yahoo.com
}

\begin{abstract}
Land dispute on forest area in Blora Regency is still developing. This is a form of resistence among Blora community toward the patterns of forrest management by Perhutani since New Order. Many things became the trigger like illegal logging, violence involving community members, and claim on land ownership. This article studied the phenomenon applying fiqh perspective in order to develop peace building that was based on common good. However natural resources management constituted an important part in doing worship to God, so it needed to be accorded to Islamic spirit.

$* * *$

Konflik sengketa tanah kawasan hutan di kabupaten Blora terus bergulir. Kisah ini merupakan sejarah lama karena resistensi masyarakat Blora terhadap pola-pola pengelolaan hutan oleh Perhutani telah dimulai sejak masa Orde Baru. Banyak hal yang menjadi pemicu persoalan seperti penebangan liar, kekerasan yang melibatkan warga, dan klaim kepemilikan atas tanah. Tulisan ini mencoba melakukan kajian secara fiqh atas fenomena tersebut, sebagai salah satu upaya mengembangkan resolusi perdamaian berdasarkan dari kemaslahatan bersama. Bagaimanapun pengelolaan atas alam merupakan bagian penting dari prosesi ibadah kepada Tuhan sehingga perlu disesuaikan dengan spirit Islam.
\end{abstract}

Keywords: sengketa tanah, fiqh, perdamaian

Walisongo, Volume 21, Nomor 1, Mei 2013 


\section{A. Pendahuluan}

Semua orang membutuhkan tanah, baik untuk tempat tinggal maupun tempat usaha. Selain nilai ekonominya tak pernah turun, ia merupakan pusat kekuasaan yang menjadi dasar kemenangan dan keunggulan seseorang. Hubungan tanah dengan kehidupan manusia sangat intim, emosional, magisreligius dan tak terpisahkan (dwitunggal). Hubungan yang bersifat demikian menyebabkan sengketa tanah tidak mudah diselesaikan.

Menurut catatan kepala Badan Pertanahan Nasional (BPN), sampai saat ini terdapat sejumlah potensi konflik dari sekitar 2.810 kasus sengketa tanah di seluruh Indonesia. ${ }^{1}$ Dalam skala regional, Jawa Tengah termasuk provinsi dengan pengaduan sengketa tanah terbanyak setelah DKI Jakarta, Jawa Timur, dan Jawa Barat sejak tahun 1994-1996. Tipe sengketa tanahnya cukup bervariasi, dari perampasan tanah dengan penggusuran, perampasan tanah tanpa ganti rugi yang layak sampai perampasan tanah dengan pembakaran bangunan diatasnya. Sedang aktor sengketa selalu melibatkan rakyat sebagai pemilik tanah versus pengusaha dan pemerintah sebagai lawannya. ${ }^{2}$

Salah satu kategori sengketa tanah yang marak terjadi pada Orde Baru dan berlanjut hingga era reformasi adalah konflik tanah akibat eksploitasi hutan. ${ }^{3}$ Pemerintah memberikan keleluasaan kepada swasta dan atau Badan Usaha Milik Negara (BUMN) untuk mengeksploitasi hutan seraya meminggirkan masyarakat sekitarnya. Atas dasar peta hutan yang berlaku di akhir kekuasaan kolonial Belanda, pemerintah membuat batas-batas hutan dari pemukiman dan tanah penduduk setempat.

Salah satu sengketa tanah kawasan hutan terjadi di Blora Jawa Tengah. Sengketa tanah ini telah berlangsung sejak zaman Belanda yang berlangsung hingga era reformasi sekarang. Warga melakukan perlawanan pada kaum kolonial dengan cara khas warga jajahan. Mental perlawanan tersebut sebagian masih melekat pada warga hingga sekarang. Bentuk perlawanan dapat berupa membangkang membayar pajak, blandong (mencuri kayu di hutan jati), bibrikan (menggarap tanah bekas tebangan blandong) dan lain-

${ }^{1}$ Joyo Winoto, dalam Kompas, 2 Juni 2007 dan Jawa Pos, 23 Mei 2007.

2 Dikutip Muhadar, Viktimisasi Kejahatan di Bidang Pertanahan, (Yogyakarta: Laksbang, 2006), h. 189-190.

${ }^{3}$ Noer Fauzi, Petani dan....op. cit, h. 198 dan seterusnya. 
lain. Ada yang menyebut, blandong sudah menjadi budaya masyarakat sekitar hutan. Penyebabnya karena mereka tak punya lahan garapan akibat ketimpangan penguasaan tanah. ${ }^{4}$

Resistensi masyarakat Blora terhadap pola-pola pengelolaan hutan oleh Perhutani terus berlanjut di masa Orde Baru. Bentrok fisik langsung antara petani dengan Perhutani terjadi berkali-kali. Sikap represif negara, dalam hal ini Perhutani, ditunjukkan dengan adanya penangkapan dan kriminalisasi terhadap orang-orang yang diduga membabat hutan dan mencuri hasilnya. Operasi Hutan Lestari (OHL)—menurut Perhutani dilakukan untuk mengatasi pencurian atau penjarahan kayu yang terjadi di kawasan hutan-yang dilakukan oleh aparat Perhutani seringkali dilakukan secara kasar dan semena-mena sehingga menimbulkan duka fisik dan batin yang tak mudah disembuhkan. Di Blora sendiri apa sajakah sengketa tanah kawasan hutan di kabupaten Blora dan bagaimana resolusi sengketa yang dilakukan dari tinjauan fiqh?

Karena tulisan ini sebagai studi lapangan (field research) dengan model studi kasus tunggal (single case study) maka asumsinya memungkinkan besar peneliti mempertahankan karakteristik holistik dan bermakna dari peristiwaperistiwa kehidupan nyata. ${ }^{5}$ Metode pengumpulan data dilakukan dengan tiga cara. Pertama, wawancara kepada sejumlah narasumber yang sudah ditetapkan sebelumnya. Wawancara dilakukan secara mendalam (indept interview) dengan pertanyaan terbuka. Narasumber yang akan diwawancarai berasal dari: (1) pejabat Perum Perhutani; (2) Lembaga Swadaya Masyarakat (LBH Semarang, Lidah Tani Blora). Kedua, observasi yaitu mengadakan pengamatan dan pencatatan secara sistematis terhadap pokok masalah yang sedang diselidiki (partisipasi pasif). Ketiga, dokumentasi yakni berupa catatan peristiwa yang sudah berlalu. Dalam konteks penelitian ini, dokumentasi yang dipakai meliputi dokumen tertulis, seperti leaflet, brosur, ketentuanketentuan hukum normatif termasuk laporan dari media massa.

Keseluruhan data yang diperoleh, kemudian didekati dalam perspektif fiqh berdasarkan kaidah-kaidah fiqhiyyah dan ușüliyyah (kaidah fiqh dan ușūl

\footnotetext{
${ }^{4}$ Rahma Mary, Dominasi dan Resistensi Pengelolaan Hutan di Jawa Tengah, (Semarang: Huma dan LBH Semarang, 2007), h. 71.

${ }^{5}$ Robert K. Yin, Studi Kasus: Desain dan Metode, (Jakarta: Rajawalipers, 2004), h. 4.
} 
fiqh) yang lazim digunakan dalam studi hukum Islam. Olahan hukum Islam dilakukan secara istiqrā'y-istinbāty (induktif-deduktif). Tata kerjanya adalah sebagai berikut; dalam hal sumber hukum Islam (dan juga hasil ijtihad ulama terdahulu dalam fiqh) tidak dapat berbicara banyak tentang tanah kawasan hutan dan masalah-masalah di sekitarnya, ia akan dikonstruks berdasarkan prinsip-prinsip menurut sumber hukum Islam. Jika sumber hukum Islam (dan juga hasil ijtihad ulama) cukup jelas menetapkan status hukum tanah kawasan hutan dan masalah disekitarnya, secara qauli konsepsi itulah yang akan digunakan dalam penelitian.

Dalam hal resolusi sengketanya, baik dalam prosedur, strategi untuk mencapai penyelesaian, maupun bentuk penyelesaian finalnya, murni berdasarkan temuan-temuan di lapangan (istiqrā'y). Untuk kemudian diangkat ke atas, apakah resolusi tersebut bertentangan dengan sumber hukum Islam atau tidak (istinbāty). Hasil dari olahan metode istiqrā'y dan istinbāty itulah yang disebut dengan perspektif fiqh.

Langkah selanjutnya adalah menganalisis secara deskriptif-kualitatif. Analisis data merupakan proses penyederhanaan data ke dalam bentuk yang lebih mudah dibaca dan diinterpretasikan. Setelah data dianalisasis, langkah selanjutnya adalah diinterpretasikan untuk mencari makna dan implikasi yang lebih luas dari hasil-hasil penelitian. Interpretasi dilakukan secara meluas dengan maksud membandingkan hasil analisanya dengan kesimpulan atau pemikiran peneliti lain atau menghubungkan dengan teori yang digunakan. ${ }^{6}$

\section{B. Sengketa Tanah dan Paradigma Resolusi Sengketa}

Dinamika pengelolaan dan konflik hutan jati di Blora memiliki sejarah yang sangat panjang. Sejak zaman kerajaan Mataram, Blora terkenal sebagai daerah penghasil kayu jati. Waktu itu, masyarakat sekitar hutan bebas membabat hutan untuk lahan pertanian dan memanfaatkan kayunya untuk dijual atau untuk tempat tinggal. Keadaan menjadi berubah ketika Belanda datang dan mulai memberlakukan peraturan yang macam-macam terhadap daerah koloninya. Belanda mulai membentuk dinas kehutanan modern yang bernama Dienst van het Boshwezen. Dinas ini yang menerapkan peraturan

6 Sofian Effendi dan Chris Manning, "Prinsip-prinsip Analisa Data” dalam Masri Singarimbun (ed.), Metode Penelitian Survei, edisi revisi, (Jakarta: LP3ES, 1989), h. 263. 
hak atas tanah, pohon dan buruh. Setiap petani yang dengan tanpa izin memasuki hutan akan ditangkap dan dikriminalisasikan. ${ }^{7}$ Warga sekitar hutan di Blora terusir dari tanahnya sendiri.

Ketika Jepang datang dan menggantikan posisi kolonial Belanda di Jawa, keadaan masyarakat setempat tidak menjadi lebih baik. Keadaannya menjadi lebih buruk karena Jepang menerapkan sistem kerja paksa. Masyarakat direkrut sebagai buruh penebang pohon jati atau pengangkut hasil hutan. Hutan jati dieksploitasi besar-besar oleh Jepang dan diangkut ke negara mereka. Setelah lahan kosong dan gundul, rakyat baru dibolehkan menggarap lahan bekas pohon jati untuk pertanian.

Ketika Indonesia merdeka, lahan hutan yang dulu milik rakyat dan kemudian dirampas oleh Belanda, dinasionalisasi oleh pemerintah. Sayangnya, lahan hutan tersebut tidak dikembalikan kepada rakyat setempat. Sejak tahun 1961, penguasaan hutan jati jatuh ke Jawatan kehutanan. Luas lahan yang dikuasai Perhutani mencapai 49,118 \% dari total wilayah Blora. Lahan tersebut hampir semuanya ditanami pohon jati. ${ }^{8}$ Dengan penguasaan lahan seluas itu dengan produksi kayu jati yang sangat strategis, Perhutani sebenarnya telah menggenggam separuh nyawa Kabupaten Blora.

Resistensi masyarakat Blora terhadap pola-pola pengelolaan hutan oleh Perhutani terus berlanjut di masa Orde Baru. Bentrok fisik langsung antara petani dengan Perhutani terjadi berkali-kali. Sikap represif negara, dalam hal ini Perhutani, ditunjukkan dengan adanya penangkapan dan kriminalisasi terhadap orang-orang yang diduga membabat hutan dan mencuri hasilnya.

\section{Asas-asas UU Kehutanan, Visi dan Misi Perum Perhutani}

UU Nomor 41 Tahun 1999 tentang Kehutanan menyatakan bahwa: “ bahwa hutan, sebagai karunia dan amanah Tuhan Yang Maha Esa yang dianugerahkan kepada Bangsa Indonesia”... (point a). Dalam UU-PA juga disebut dengan kalimat yang kurang lebih sama bahwa: “....... bumi, air, dan ruang angkasa, sebagai karunia Tuhan Yang Maha Esa mempunyai fungsi yang amat penting...." Aspek ilāhiyyah ini adalah pengakuan awal bahwa tanah adalah semata-mata karunia Tuhan dan manusia tinggal memanfaat-

${ }^{7}$ Rahma Mary, dkk, Dominasi dan Resistensi ..., h. 64.

8 Ibid., h. 61. 
kannya saja. Asas ini seyogyanya mendasari dan menjiwai seluruh pasalpasal lainnya, termasuk implementasinya di lapangan. Seandainya terjadi sengketa antar para pihak, penyelesaiannya pun hendaknya tidak lepas dari asas Ilahiyah ini.

UU Kehutanan ini juga menganut asas "dikuasai oleh negara." Asas ini menyatakan bahwa "... hutan, sebagai karunia dan amanah Tuhan Yang Maha Esa yang dianugerahkan kepada Bangsa Indonesia, merupakan kekayaan yang dikuasai oleh Negara, memberikan manfaat serbaguna bagi umat manusia ...." (Pasal 4). Di samping asas HMN di atas, UU Kehutanan juga menganut asas manfaat, lestari, kerakyatan, keadilan, kebersamaan, keterbukaan dan keterpaduan. Asas-asas lainnya dalam pengelolaan dan penyelenggaraan hutan seperti kerakyatan, keadilan, kebersamaan, keterbukaan dan keterpaduan lebih merupakan harapan dan cita-cita agar penyelenggaraan memberikan kemakmuran bagi semua, baik untuk negara (yang dalam hal ini diwakili oleh Perum Perhutani) maupun untuk masyarakat luas dan lebih khusus masyarakat sekitar hutan.

Menghadapi konflik berhadapan warga sekitar hutan, Perum Perhutani sudah menyadari pentingnya pendekatan baru yaitu pendekatan kesejahteraan (prosperity approach). ${ }^{9}$ Wujud pendekatan kesejahteraan ini diantaranya adalah melalui program Bimas/Inmas/Insus Tumpangsari, Pembangunan Masyarakat Desa Hutan (PMDH) dan disusul dengan program perhutanan sosial (Social Forestry) sejak tahun 1980-an dan program-program lain yang disusun oleh masing-masing Perum Perhutani di wilayah-wilayah yang berbeda. ${ }^{10}$

Visi Perum Perhutani adalah Menjadi Pengelola Hutan Tropis Terbaik di Dunia. Sedangkan misinya adalah: (1) Mengelola hutan tropis dengan prinsip Pengelolaan Hutan Lestari Bersama Masyarakat; (2) Meningkatkan produktivitas, kualitas dan nilai sumberdaya hutan; (3) Mengoptimalkan manfaat hasil hutan kayu, non kayu dan jasa lingkungan serta potensi lainnya, dalam rangka meningkatkan pendapatan dan keuntungan perusahaan serta kesejahteraan masyarakat (sekitar hutan); (4) Membangun sumberdaya

${ }^{9}$ H. Simon, Merencanakan Pembangunan Hutan untuk Strategi Kehutanan Sosial, (Yogyakarta: Aditya Media, 1994), h. 16.

10 M. Prakosa, Rencana Kebijakan Kehutanan, (Yogyakarta: Aditya Media, 1996), h. 125-132. 
manusia perusahaan yang bersih, berwibawa dan profesional; (5) Mendukung dan berperan serta dalam pembangunan wilayah dan perekonomian daerah.

\section{Paradigma Resolusi Sengketa}

\section{Paradigma dan Karakteristik Resolusi Sengketa Litigasi}

Proses penyelesaian sengketa di pengadilan sering disebut dengan penyelesaian sengketa secara litigasi. Litigasi merupakan proses (penyelesaian sengketa—pen) administrasi dan peradilan, yang sangat familiar bagi para lawyer dengan karakteristik adanya pihak ketiga yang mempunyai kekuatan untuk memutuskan (to impose) di antara para pihak yang bersengketa. Litigasi biasanya menghasilkan keputusan kalah/menang.

Dengan mengikuti pola hukum modern, maka karakteristik penyelesaian sengketa secara hukum (litigasi), antara lain: (1) Pengadilan dianggap satu-satunya institusi yang dapat menyelesaikan sengketa; 2) Berkepastian hukum; (3) Kebenaran hukum adalah kebenaran yang dibuktikan oleh alatalat bukti yang disahkan oleh hukum; (4) Secara yuridis, suatu sengketa hukum dinyatakan selesai apabila hakim telah membuat putusan yang berkekuatan hukum tetap; (5) Lama dan mahal.

\section{Paradigma, Jenis dan Karakteristik Resolusi Sengketa Non-Litigasi}

Mengenai resolusi sengketa di luar pengadilan, Kubasek dan Silverman menggunakan istilah extrajudicial settlement of disputes atau populer dengan istilah alternative dispute resolution (ADR). Dalam kepustakaan Indonesia, ADR disebut pula Mekanisme Penyelesaian Sengketa Secara Kooperatif (MPSSK), atau Mekanisme Alternatif Penyelesaian Sengketa (MAPS).

Penyelesaian sengketa non-litigasi sebenarnya dapat dilakukan baik di dalam (inside the court) maupun di luar pengadilan (outside the court). Dalam beberapa literatur, penyelesaian sengketa non-litigasi di dalam pengadilan atau kadang disebut dengan Court Connected ADR atau ADR Inside the Court atau Court Dispute Resolution (CDR), dapat berupa, misalnya perdamaian di pengadilan. Dalam sistem hukum acara di Indonesia, pranata perdamaian di pengadilan di sebut dading. Pada sisi lain, pranata penyelesaian sengketa non- 
litigasi di luar pengadilan diantaranya meliputi negosiasi, mediasi, konsiliasi dan lain-lain.

Beberapa keuntungan yang dapat dipetik apabila penyelesaian semacam ini dilaksanakan, yaitu: (1) Untuk mengurangi kemacetan dan penumpukan perkara (court congestion) di lembaga peradilan; (2) Untuk meningkatkan keterlibatan masyarakat (desentralisasi hukum) atau memberdayakan pihakpihak yang bersengketa dalam menyelesaikan masalahnya; (3) penyelesaian sengketa yang menghasilkan keputusan saling menguntungkan (win-win solution); (4) Penyelesaian perkara lebih cepat dan dan biaya murah; (5) Bersifat tertutup atau rahasia (confidential); (6) Lebih tinggi kemungkinan dilaksanakannya kesepakatan bersama sehingga hubungan pihak-pihak yang bersengketa di masa depan masih dimungkinkan terjalin dengan baik.

\section{E. Memotret Blora dan Sengketa Tanahnya}

Menurut cerita rakyat, Blora berasal dari kata Belor yang berarti lumpur. Kemudian kata Belor berkembang menjadi mbeloran yang sekarang dikenal dengan nama Blora. Secara etimologis, Blora dari kata Wai dan Lorah (Wailorah). Wai berarti air dan Lorah berarti jurang atau tanah rendah. Dalam bahasa Jawa, huruf $\mathrm{W}$ kadang berubah menjadi B, tanpa merubah arti katanya. Seiring dengan perkembangan zaman, kata Wailorah menjadi Bailorah, dari kata Bailorah menjadi Balora. Dari Balora ini kemudian berkembang menjadi Blora. Jadi nama Blora berarti tanah rendah berair, yang dekat sekali dengan pengertian tanah lumpur. ${ }^{11}$

H.J. De Graaf dan TH. Pigeaud dalam buku Kerajaan Islam Pertama di Jawa: Tinjauan Sejarah Politik Abad XV dan XVI menyebutkan bahwa Blora di masa lalu disebut Mendang Kamulan atau Medang Kamulan. Suatu tempat yang dalam mitos Jawa sering disebut sebagai tempat asal keturunan rajaraja Jawa tertua. ${ }^{12}$ Blora berubah menjadi kabupaten pada tanggal 11 Desember 1749, dengan bupati pertama bernama Wilatikta. Kini, Blora adalah salah satu kabupaten di Provinsi Jawa Tengah. Kabupaten ini berbatasan dengan Kabupaten Rembang dan Kabupaten Pati di utara, Kabupaten Tuban

11 http://www.pemkabblora.go.id. Diakses tanggal 19 Agustus 2008.

12 H.J. De Graaf dan TH. Pigeaud dalam buku Kerajaan Islam Pertama di Jawa: Tinjauan Sejarah politik Abad XV dan XVI, cet. Iv, (Jakarta: Pustaka Utama Grafiti, 2001), h. 66. 
dan Kabupaten Bojonegoro (Jawa Timur) di sebelah timur, Kabupaten Ngawi (Jawa Timur) di selatan, serta Kabupaten Grobogan di barat.13 Kabupaten Blora terdiri atas 16 kecamatan, yang dibagi lagi atas sejumlah desa dan kelurahan. Jumlah penduduk hasil registrasi pada akhir 2002 oleh BPS Kabupaten Blora tercatat sebanyak 833.506 jiwa. separuh dari wilayah Kabupaten Blora merupakan kawasan hutan (49,66 \%), baik berupa hutan negara atau hutan rakyat, terutama di bagian utara, timur, dan selatan.

Seperti telah dinyatakan di atas, 49,66 \% luas kabupaten Blora merupakan kawasan hutan yang dikelola oleh Perum Perhutani I Jawa Tengah dan terbagi atas tiga kesatuan pemangkuan hutan (KPH), yaitu KPH Randublatung, KPH Cepu dan KPH Blora. Produksi kayu jati bundar terbanyak berasal dari Kecamatan Randublatung yakni sebesar 35.310,000 m3 yang termasuk di wilayah Randublatung. Total produksi kayu jati bundar di Kabupaten Blora tahun 2002 sebesar 85.950,197 m3 atau turun sebesar 14,28 persen dari tahun sebelumnya. Dengan tanah kawasan hutan yang luas tersebut,sengketa tidak dapat terhindarkan.

\section{Kasus-kasus dan Faktor Penyebab Sengketa Tanah}

Di antara 3 KPH lainnya (KPH Blora, KPH Cepu), KPH Randublatung adalah yang paling banyak timbul masalah. Dengan jumlah penduduk sekitar 73 ribu jiwa (17 ribu KK atau 4 jiwa/RT), yang berarti kepadatan sebesar 300 jiwa $/ \mathrm{km}^{2}$, terlihat bahwa Randublatung tergolong padat penduduk. Secara geografis, interaksi masyarakat desa hutan (MDH) di Randublatung dengan hutan di sekitar tempat hidup mereka sangat tinggi. Salah satu indikatornya adalah bahwa dari wilayah Kecamatan Randublatung seluas 21.113,097 hektare, 13.366,605 hektar di antaranya (64\%) merupakan kawasan hutan Perum Perhutani.

\section{a. Fenomena Penebangan Liar}

Selama dua bulan pada tengah tahun pertama 1998 saja, kasus pencurian massal di beberapa wilayah Perhutani Unit I Jateng telah mengakibatkan hilangnya asset senilai hampir 300 juta rupiah. Dalam konteks itu, kerugian KPH Randublatung tercatat mendekati Rp. 80 juta akibat hilangnya

13 http://www.pemkabblora.go.id diakses tanggal 19 Agustus 2008. 
sekitar 5.000 batang kayu jati. Penebangan liar atau penjarahan hutan, salah satunya dipicu oleh kesalahpahaman dalam kerja sama antara oknum perangkat desa Temulus dengan oknum Perhutani setempat.

Meskipun pemicu awal konflik terjadi di Temulus, namun warga masyarakat yang memasuki hutan untuk mengambil kayu ternyata juga berasal dari tempat-tempat lain seperti Bapangan, Pilang, Karanganyar, Bodeh, Balongkare, dan Plosokediren. Pada perkembangannya, penjarahan hutan di wilayah BKPH Beran telah melibatkan beberapa organisasi pencurian kayu yang selama ini telah eksis di wilayah Randublatung dan sekitarnya. Pengambilan kayu di hutan secara terorganisir juga ditandai banyaknya pihak yang terlibat mulai dari buruh pencuri, buruh pengangkut (manol), pimpinan pencuri (blandong), oknum aparat desa, pemilik modal, petugas Perhutani, hingga aparat keamanan.

\section{b. Perselisihan antara Masyarakat Desa Hutan (MDH) dan Aparat Perhutani}

Hubungan kedua pihak berada pada titik nadzir (rawan), akibat banyaknya penangkapan terhadap warga yang mengambil rencek (ranting-ranting, dahan dan kayu-kayu kering untuk kayu bakar) di lokasi hutan. Menurut Perhutani, rencek yang dimaksud bukan sekedar rencek tapi juga kayu-kayu jati yang bernilai ekonomi tinggi. Beberapa kali wakil masyarakat mencoba menjelaskan dan bernegosiasi tentang masalah ini, namun pihak Perhutani bersikeras menggelar operasi, sampai ke rumah-rumah penduduk. ${ }^{14}$

\section{c. Kekerasan Menjadi Pemandangan yang Umum pada Sengketa Tanah Kawasan Hutan}

Pada tahun 1998, Perhutani menembak dua orang warga yang sedang mencari kayu di Hutan. Dua orang tersebut adalah Darsit dan Rebo. Setelah kejadian salah tembak itu, masyarakat melakukan pengrusakan bangunan Perhutani yang ada di Randublatung dan melakukan tindakan pembalasan dengan mengambil kayu di hutan jati. Pada tahun 2000 kekerasan oleh Polisi Hutan kembali terjadi. Kali ini di KPH Cepu yang menewaskan Djani. Djani

14 Faisal H. Fuad, "Kajian Kasus Penjarahan Hutan di KPH. Randublatung," dalam http://www.arupa.or.id diakses tanggal 19 Agustus 2008. 
ditembak saat Polisi Hutan sedang melakukan operasi pengamanan hutan. Padahal Djani bukanlah pencuri kayu. Pagi itu dia pergi ke sawah membawa cangkul. Kebetulan polisi hutan sedang mengejar pencuri kayu dan mendapati Djani di lokasi, polisi hutan menembaknya sampai tewas.

Kekerasan yang sama terus berulang di Blora, baik yang menyebabkan tewasnya warga masyarakat maupun yang luka-luka. Korban-korban yang tewas di Blora dalam rentang waktu 1998-2008 dijelaskan di bawah:15

\begin{tabular}{|c|l|l|l|l|}
\hline No. & \multicolumn{1}{|c|}{ Nama } & \multicolumn{1}{c|}{ Modus } & \multicolumn{1}{c|}{ KPH } & \multicolumn{1}{c|}{ Waktu } \\
\hline 1 & Darsit & Penembakan & Randublatung & 28 Juni 1998 \\
\hline 2 & Rebo & Penembakan & Randublatung & 28 Juni 1998 \\
\hline 3 & Djani & Penembakan & Cepu & 5 November 2000 \\
\hline 4 & Wiji & Penganiayaan & Cepu & 14 Otober12002 \\
\hline 5 & Musri & Penembakan & Randublatung & 16 Desember 2003 \\
\hline 6 & Nurhadi & Penganiayaan & Randublatung & 13 Juni 2006 \\
\hline 7 & Pariyono & Penganiayaan & Randublatung & 18 November 2006 \\
\hline
\end{tabular}

Beberapa contoh kasus di atas menunjukkan bahwa sengketa hutan cenderung terjadi tindak kekerasan di antara para pihak yang terlibat sengketa. Catatan dari Arupa menguatkan asumsi itu. ${ }^{16}$ Dalam sepuluh tahun terakhir sudah 7 (tujuh) orang tewas ditangan Perhutani di Blora. Apabila dikalkulasikan untuk Jawa Tengah (Wilayah I Perhutani), sebagaimana ditabulasikan oleh LBH Semarang dan Lidah Tani, dalam sepuluh tahun terakhir (1998-2008.) sudah 31 orang tewas dan 69 orang luka-luka akibat pendekatan keamanan yang dilakukan oleh Perhutani. ${ }^{17}$

\section{d. Sengketa Hutan yang Berbasiskan (Hak Atas) Tanah ${ }^{18}$}

Konflik ini berlatar belakang pengambilalihan tanah-tanah hasil membuka hutan atau tanah-tanah garapan masyarakat oleh Perum Perhutani. Klaim

\footnotetext{
15 Data diolah dari tabulasi dokumen kasus yang dikumpulkan LBH Semarang dan Lidah Tani, sebagaimana dikutip Yance Arizona, ibid.

16 Edi Suprapto, "Konflik Kehutanan yang Berbuah Kekerasan," dalam http://www. arupa.or.id. diakses tanggal 20 Agustus 2008.

17 Wawancara dengan Lukito, Koordinator Lidah Tani Blora, Juli 2008.

18 Wawancara dengan Siti Rahma MH, advokat di LBH Semarang, tanggal 20 Juli 2008.
} 
penguasaan tanah hutan memiliki dampak sangat serius bagi petani sekitar hutan karena mereka harus berhadapan dengan Perum Perhutani yang memiliki kekuatan penuh untuk memeriksa, menggeledah, menyita, menangkap dan menahan seseorang yang diduga melakukan tindak pidana yang menyangkut hutan (UU No. 41 Tahun 1999 tentang Kehutanan, Pasal 77).

\section{Resolusi Sengketa Tanah Kawasan Hutan}

\section{a. Perum Perhutani}

\section{1) Solusi Hukum dan Keamanan}

Cara-cara menyelesaikan sengketa tanah dengan hukum negara biasanya dilakukan oleh pihak-pihak yang-merasa-memiliki bukti-bukti hukum yang kuat. Hal itu ditunjukkan pada kasus sengketa tanah yang melibatkan warga dengan Perhutani. Penyelesaian sengketa tanah kawasan hutan pada masa Orde Baru menggunakan cara-cara demikian. Pemerintah yang otoriter akan menggunakan hukum represif untuk menyelesaikan masalahnya. Siapa saja yang dianggap melanggar, akan ditindak sesuai dengan UU No. 41 Tahun 1999 tentang Kehutanan.

\section{2) Kerja sama dengan MDH}

Untuk menyelesaikan konflik yang telah terjadi, bukan hanya pendekatan keamanan dan hukum yang dipilih oleh Perhutani. Perhutani menawarkan mekanisme penyelesaian berupa program Pengelolaan Hutan Bersama Masyarakat (PHBM/ Managing Forest with Community), yang pada era Orde Baru disebut kerja sama model tumpangsari.

PHBM merupakan sistem pengelolaan sumber daya hutan yang dilakukan oleh perusahaan (perum Perhutani) dan masyarakat kawasan hutan dengan semangat berbagi agar manfaat sumber daya hutan dapat terwujud secara optimal. Semangat yang dibangun oleh Perum Perhutani dengan PHBM ini adalah kemauan (willingness) masyarakat sekitar hutan dan pihakpihak lain yang tertarik untuk berbagi dalam pengelolaan sumber daya hutan berdasarkan prinsip-prinsip keseimbangan-keberlanjutan, kesesuaian dan keselarasan dalam pengelolaan hutan. 


\section{b. Masyarakat Sekitar Hutan}

Tidak mudah bagi MDH untuk mengajak berdialog dengan Perhutani. Apa yang dikatakan oleh MDH sebagai masalah, belum tentu dianggap Perhutani sebagai masalah. Masalah tidak adanya akses masyarakat MDH untuk ikut memanfaatkan hutan, awalnya tidak dianggap masalah. Begitu pula dengan klaim atas hak atas lahan hutan yang dulu milik MDH, termasuk aparat hutan yang over acting, operasi hutan lestari yang sering menimbulkan ketakutan di tengah masyarakat, awalnya juga bukan dianggap masalah oleh Perhutani. Buktinya pada masa Orde Baru, MDH terasa adem ayem, seperti tidak ada masalah. Hanya setelah reformasilah, MDH berani bersuara untuk menuntut haknya.

Ini akan dijelaskan beragam strategi dan mekanisme yang digunakan warga yang tinggal di pinggiran kawasan hutan untuk mendapat hak hukumnya.

\section{1) Mengorganisir Diri}

Di Blora, para petani yang berseteru dengan Perhutani membentuk kelompok-kelompok tani yang disebut Lembaga Rembug Hutan (LRH). Kelahirannya difasilitasi oleh Aliansi Relawan untuk Penyelamatan Alam (Arupa; suatu aliansi yang terdiri dari beragam latar belakang, termasuk para mahasiswa). Pada tahun 2003, setelah melakukan studi banding di beberapa daerah dan berdiskusi panjang, petani membentuk Organisasi Tani Lokal (OTL) yang bernama Lidah Tani yang berarti "Api Perlawanan Petani." Lidah Tani mengorganisir petani hutan, belajar bersama, dan membangun jaringan dengan petani se-Jateng dengan satu tujuan utama agar yakni memperjuangkan keadilan petani yang tinggal di sekitar kawasan hutan. ${ }^{19}$

Penggunaan organisasi atau paguyuban atau forum sebagai suatu strategi untuk memperjuangkan hak-hak atas tanah adalah gejala baru gerakan hukum petani sebagai upaya untuk 'memaksa' pihak yang berlawanan mau duduk berunding dan mencari penyelesaian sengketa yang saling menguntungkan. Tanpa mengorganisir diri atau bergerak secara individual, protes dan tuntutan para petani tak akan digubris oleh Perhutani.

${ }^{19}$ Rahma Mary, et. al., Dominasi dan Resistensi..., h. 74. 
Gerakan, protes atau tuntutan yang dilakukan dengan menggunakan wadah atau institusi tertentu kemungkinan besar akan direspon oleh pihak yang dituntut. Institusi atau organisasi tersebut dalam istilah sosiologi Berger dan Neuhaus disebut sebagai 'mediating structures' (institusi-institusi mediasi) yang wujud konkretnya merujuk pada lembaga keluarga, ketetanggaan, keagamaan dan juga asosiasi keswadayaan..$^{20}$

\section{2) Kerjasama dan Komunikasi hukum}

Kerja sama dan menjalin hubungan dengan pihak lain adalah bagian dari karakter manusia sebagai makhluk sosial. Setiap orang merasakan betapa kehadiran orang lain sangat penting dalam rangka memenuhi kebutuhan untuk kelangsungan hidupnya. Naluri untuk berjuang hidup ini (survival of fittes) membuat manusia selalu bergantung pada orang lain, baik masa sekarang maupun yang akan datang. Selain naluri berjuang untuk hidup, naluri mempertahankan diri dari berbagai ancaman juga membutuhkan kerja sama dengan pihak lain. Perasaan aman akan didapat apabila pertahanan diri dilakukan bersama-sama. Oleh karena itu, ia akan mencari teman sepaham dan seperjuangan yang dapat dipercaya. Untuk memperoleh kawan seperti itu, ia harus menjalin hubungan dan komunikasi dengan banyak kalangan. Dalam upaya komunikasi tersebut terdapat unsur-unsur untuk membangunan citra yang baik (good image), itikad baik (good will), meyakinkan, mempengaruhi, menanamkan kepercayaan (trust) dan lain-lain. Akses informasi yang terbuka lebar ini merupakan buah dari pengorganisasian yang dilakukan para petani. Secara rutin dan periode mereka mendapat informasi yang dibutuhkan tentang apa saja yang berkaitan dengan tuntutan mereka.

\section{3) Aksi Demonstrasi}

Strategi yang menjadi pilihan warga dalam mencapai penyelesaian sengketa yang komprehensif adalah melakukan aksi demonstrasi. Demonstrasi pada hakekatnya merupakan salah satu cara untuk menampakkan aspirasi ataupun pendapat secara bersama-sama. Biasanya dilakukan di jalan-jalan

${ }^{20}$ Dalam sosiologi, teori ini disebut teori struktur-struktur mediasi (mediating structures). Baca Peter L. Berger dan Richard J. Neuhaus, To Empower People: The Role of Mediating Structures in Public Policy, (Washington: American Institute for Public Policy Research, 1977), h. 1-7. 
atau tempat-tempat strategis, melakukan orasi, yel-yel dan lain sebagainya. Kadang-kadang juga diselingi dengan penyebaran pamflet atau leaflet tentang tuntutan mereka. Sebagai wujud kebebasan berekspresi dan berpendapat di depan umum, demontrasi dianggap sebagai strategi penting untuk membawa sengketa tanah ke ranah publik.

\section{4) Pembabatan dan Perlawanan Menuntut Balas}

Pembabatan pohon jati adalah salah satu strategi MDH untuk menuntut haknya. Motifnya adalah merusak atau menebang pohon jati milik Perhutani dan bukan berniat untuk blandong atau mencuri atau menjarah kayu. Aksi ini sering dilakukan sebagai respon terhadap perilaku aparat Perhutani yang dianggap berlebihan kepada warga, terutama di awal reformasi ketika warga kecewa dengan perlakuan Perhutani selama ini. Setelah itu aksi ini telah ditunggangi dengan kepentingan tertentu, seperti motif ekonomi dan melibatkan jaringan yang sistematis dan luas, seperti masyarakat, para cukong atau penadah kayu curian, oknum Perhutani, oknum TNI, oknum Polri dan lain-lain.

\section{5) Lobi dan Negosiasi}

Dalam paradigma penyelesaian sengketa non-litigasi, lobi bukanlah bagian dari mekanisme penyelesaian sengketa. Istilah lobi lebih menonjol digunakan di arena politik.Terkait dengan penelitian ini, lobi merupakan bagian dari strategi menuju pada penyelesaian sengketa tanah yang adil. Masing-masing pihak-baik perusahaan maupun petani-melakukan lobidalam arti mempengaruhi para pengambil keputusan di bidang tanahuntuk memenangkan perkaranya. Dalam lobi dimaksudkan untuk me-yakinkan dan menyatukan pandangan antara para pengambil keputusan dengan pihak yang sedang bermasalah.

Meskipun hampir semua masalah sengketa tanah diawali dengan negosiasi, tapi tidak ada yang berhasil hanya dengan satu mekanisme saja. Dalam sengketa tanah, pihak negara sudah terlibat intensif sejak awal, baik mengenai penentuan apa yang dimaksud dengan hak atas tanah, pemberian hak, pendaftaran hak hingga melegalkan hak atas tanah tersebut. Penyelesaian sengketa tanah tidak mungkin terjadi tanpa intervensi negara sebab negaralah yang melegalkan hak atas tanah itu. 


\section{6) Mediasi}

Pelaksanaan mediasi pada kasus penyelesaian sengketa tanah sangat berbeda dengan model mediasi lainnya. Dalam sengketa tanah yang melibatkan para petani dengan Perum Perhutani (sengketan lahan kawasan hutan), para petanilah yang aktif meminta bantuan pihak ketiga (mediator) untuk membantu menyelesaikan masalahnya. Pihak ketiga yang diminta menjadi mediator biasanya kepala daerah (bupati atau gubernur) dan atau Dewan Perwakilan Rakyat Daerah (DPRD).

Yang perlu dicatat dan hal ini yang membedakan dengan mediasi di pengadilan atau mediasi singketa bisnis, termasuk berbeda dengan konsepkonsep teoritis adalah; pertama, bahwa kehadiran pihak ketiga itu (mediator) belum tentu disetujui oleh pihak lawan; kedua, pihak ketiga tersebut juga bukan dari kalangan profesional yang memang terdidik atau dididik untuk menjadi mediator; ketiga, netralitas atau ketidakberpihakan dipertanyakan oleh karena keduanya merupakan lembaga politik.

\section{F. Perspektif Fiqh Resolusi Sengketa Tanah Kawasan Hutan}

\section{Hutan dan Pengelolaannya dalam Perspektif Fiqh}

Dalam konteks Islam, hak milik dapat dibagi menjadi tiga macam, yaitu hak milik pribadi, hak milik negara dan hak milik umum. Yang dimaksud hak milik pribadi adalah kepemilikan semua hal kecuali yang ditentukan lain oleh agama. Hak milik Negara merupakan hak seluruh umat di mana pengelolaannya diserahkan pada Negara. Sedangkan hak milik kolektif adalah hak milik umum untuk memanfaatkannya secara bersama-sama. Benda-benda yang termasuk dalam kategori pemilikan umum telah dinyatakan sendiri oleh Nabi Muhammad SAW yang dilarang dimiliki oleh orang baik secara sendiri maupun kelompok. Dalam hal hak milik pribadi tidak ada kesulitan untuk menterjemahkannya. Namun dua hak selebihnya, terdapat perbedaan signifikan yang patut dipahami.

Tanah yang termasuk hak milik umum pada dasarnya tidak boleh diberikan oleh Negara kepada siapapun atau pihak manapun, meskipun Negara dapat memberikan hak pengelolaan atau penggunaan yang memungkin tanah dapat dimanfaatkan secara maksimal. Sedangkan hak milik Negara, Negara berhak memberikan hak (baik hak milik maupun penge- 
lolaan) kepada pihak-pihak tertentu. Dalam konteks wacana hukum tanah nasional, hak milik Negara merupakan objek landreform yang dapat dibagikan kepada rakyat Indonesia.

Dalam konteks hak di atas, tanah kawasan hutan dapat dimaknai sebagai tanah milik kolektif atau tanah milik Negara tergantung dari sifat hutannya. Pendapat ini didasarkan pada spirit hadits yang disabdakan oleh Nabi Muhammad SAW bahwa: "kaum Muslimin berserikat dalam tiga hal, yaitu air, padang dan api." Dari substansi makna, pengertian air dan api tidak menimbulkan perbedaan pendapat. Tidak demikian hal dengan pengertian padang. Padang adalah lahan cukup luas yang diatasnya tumbuh rumput dan pohon yang biasanya digunakan untuk menggembala ternak. Dari pengertian ini, sawah, ladang, lahan perkebunan bukan termasuk padang. Dari pengertian ini, kawasan hutan lebih dekat dengan konsepsi padang sebagaimana hadits di atas. Namun hutan dalam konteks Indonesia tidak hanya hutan lindung, tetapi ada juga hutan produksi.

Selain padang, pada masa Nabi dikenal pula istilah himā yakni suatu kawasan yang khusus dilindungi oleh pemerintah (negara atau khiläfah) atas dasar syariat guna melestarikan kehidupan liar serta hutan. Nabi Muhammad pernah mencagarkan kawasan sekitar Madinah sebagai himā guna melindungi lembah, padang rumput dan tumbuhan yang ada di sekitarnya. Nabi melarang masyarakat mengolah tanah tersebut karena lahan itu untuk kepentingan umum dan pelestarian alam. Lahan hima ini cukup luas di Madinah, sekitar 2.049 ha. Nabi bersabda: "Tidak ada himā kecuali milik Allah dan Rasulnya" (lā himā illā lillāhi wa li rasūlihi). Mengikuti jejak Nabi Muhammad, khalifah Abu Bakar, Umar Ibn al-Khattab dan Utsman ibn Affan juga menetapkan suatu kawasan sebagai himā. ${ }^{21}$

Tentang pengelolaan himima ini, al-Mawardi menjelaskan bahwa jika suatu lahan resmi (dinyatakan) sebagai lahan yang dilindungi maka ia menjadi milik umum, maka dilarang untuk menghidupkannya (digarap) atau untuk dimiliki. Semua orang berhak memanfaatkannya namun tidak diperkenankan merubah sifat lahan menjadi lahan pertanian. Larangan demikian ini, sematamata untuk konservasi alam dan kemaslahatan manusia. ${ }^{22}$

\footnotetext{
${ }^{21}$ Sebagaimana dikutip Fachruddin M. Mangunwijaya, Konservasi Alam dalam Islam, (Jakarta: Yayasan Obor Indonesia, 2005), h. 53-4.

22 Ibid., h. 54 dan seterusnya.
} 
Konsep kawasan lindung ini, menurut pendapat Umar, didasarkan pada asumsi bahwa hewan-hewan yang dipergunakan untuk berperang sangat membutuhkan tanah atau kawasan yang dapat menjaga kelangsungan hidupnya (misalnya untuk mencari makan, menjaga kebugaran dan pemeliharaan yang bernuansa alami-pen). Oleh karena itu, Umar membuat keputusan untuk menyediakan kawasan khusus milik negara (yang tidak dimiliki oleh siapapun) untuk menggembalakan kuda-kuda, onta atau ternak lainnya. Bahkan Umar juga mempersilakan penggembala kecil untuk ikut memanfaatkan kawasan lindung tersebut. Urusan penyediaan (padang) rumput ini, menurut Umar juga menjadi tanggung jawabnya. Sebagaimana diriwayatkan Abu Ubaid, bahwa Umar membuat kawasan lindung untuk menempatkan dan menggembalakan kuda perang kaum Muslimin dan binatang ternak hasil zakat (hal tersebut telah dilaksanakan sebelumnya oleh Rasulullah). Tashrī' penyediaan kawasan lindung oleh Umar merupakan implementasi dari sabda Rasulullah SAW.23

Dalam konteks kekinian, hima identik dengan hutan lindung atau padang sebagaimana hadits Nabi di atas. Himā atau padang hanya dapat dimanfaatkan secara bersama-sama dan tidak boleh dijadikan sebagai lahan pertanian. Memanfaatkan tidak dalam arti menebang hingga habis pohon di atasnya yang demikian itu justru malah merusaknya. Memanfaatkan yang dimaksud tetap dalam konteks konservasi alam, yang sangat mirip dengan pengelolaan hutan oleh warga sekitar hutan sebelum penjajah Belanda datang.

Hutan yang dikelola oleh Perhutani termasuk kategori hutan produksi (lahan yang diusahakan secara produktif oleh perusahaan milik negara) yang belum ada presedennya dalam Islam. Namun meskipun hutan produksi, tetap saja ia mengemban amanat sebagai lahan konservasi alam yang harus dikelola sangat berbeda dengan lahan sawah atau ladang. Hutan apapun jenisnya lebih dekat dengan pengertian hima atau padang yang dengan hak milik kolektif. Dalam prakteknya di Indonesia hutan lebih diatribusi sebagai hak milik negara (atau perusahaan) yang dikelola dengan cara-cara sebagaimana hak milik pribadi.

Cara pengelolaan hutan yang represif sebenarnya sangat berlawanan dengan konsep maslahat. Pengelolaan yang maslahah adalah pemanfaatan

${ }^{23}$ Muhammad Baltaji, Metodologi Umar bin al-Khathab, (Jakarta: Khalifa, 2005), h. 217. 
yang seimbang antar konservasi alam dan untuk manusia. Begitu pula antara Perhutani dengan warga sekitar. Apalagi apabila warga sekitar tidak memiliki lahan lain selain tanah yang sekarang diklaim sebagai lahan kawasan hutan.

Dalam ilmu ushul fiqh dikenal istilah al-mașlahah, al-mașlahah almursalah, al-mașlaḥah al-āmmah, dan al-hajjah al-'āmmah. Al- mașlaḥah dari kata kerja șaluha, secara bahasa berarti baik (good), damai (peace, conciliation), pantas (proper), manfaat (useful), kepentingan (benefit, interest), kemaslahatan dan lain-lain. Al-mașlaḥah al-'ämmah, mașlaḥah al-mursalah dan al-hajjah al-'âmmah dapat berarti public welfare, commonweal (kesejahteraan umum/ bersama. Dalam al-Qur'an, beberapa kata jadian dari ș-l-h memang digunakan, tetapi kata mașlaḥah tidak disebutkan. Al-Qur'an menggunakan kata zalama (5: 39) dan fasada (26:125, 27:142, 2:220) sebagai lawan dari kata șaluha.

Dalam pandangan Shatibi dalam teori maqāṣid sharīah, menjelaskan bahwa tujuan akhir hukum adalah satu, yaitu mașlahah atau kebaikan dan kesejahteraan umat manusia. Baginya, yang dimaksud dengan mașlahah adalah mașlahah yang membicarakan substansi kehidupan manusia dan pencapaian apa yang dituntut oleh kualitas emosional dan intelektual secara mutlak. Shatibi membagi maqāṣid atau mașālị̣ (jamak dari mașlaḥah) menjadi ḍaūry (primer/ keharusan), hajjy (sekunder/dibutuhkan) dan tahsiny (tersier/ pelengkap). ${ }^{24}$

Menurut sebagian ulama, ada lima kriteria al-mașlahah al-'āmmah yang dapat dijadikan patokan. Pertama, sesuatu yang manfaatnya dirasakan oleh seluruh atau sebagian besar masyarakat. Kedua, selaras dengan tujuan syari'ah yang terangkum dalam al-kulliyyat al-khamsah. Ketiga, manfaat yang dimaksud harus nyata (hakiki) bukan sebatas perkiraan (wahmi). Keempat, tidak boleh bertentangan dengan al-Qur'an dan Hadits. Kelima, tidak boleh dilaksanakan dengan mengorbankan kepentingan umum lain yang sederajat apalagi yang lebih besar. ${ }^{25}$

Seperti telah dijelaskan di atas, status hukum tanah kawasan hutanmenurut fiqh—adalah hak milik kolektif, yang dalam praktek penguasaan

${ }^{24}$ Muhammad Khalid Mas'ud, op. cit, h. 230 dan seterusnya.

25 Al-Zuhaili, Ushel al-Fiqh al-Islqāmy, juz II, h. 1028. Sa'id Ramadhan al-Buthi, Dawābit alMaṣlaḥah fi al-Sharīah al-Islämiyyah, (Beirut: Mu’assasah al-Risalah, 1986), h. 254. 
tanah hutan di Indonesia menggunakan asas Hak Menguasai Negara (HMN). Sungguhpun asas HMN sangat ideal diterapkan, di mana negaralah yang diberi kewenangan mengatur dan mengelola hak milik bangsa. Asas HMN cenderung state heavy di satu sisi, dan di sisi lain pelaksanaannya kemudian diserahkan kepada pemerintah. Pemerintah juga masih menyerahkan pengaturannya kepada departemen sektoral dan dari departemen diserahkan kepada badan atau perusahaan. Untuk kasus kehutanan, dari Departemen Kehutanan diserahkan kepada Perum Perhutani. Jadi penyerahan ininegara kepada pemerintah kepada Departemen Kehutanan kepada Perum Perhutani-adalah bentuk pergeseran yang telah menjadikan implementasi HMN justru menciderai HMN itu sendiri.

Terkait dengan dua akar masalah utama sengketa tanah kawasan hutan di kabupaten Blora, pendirian fiqh adalah sebagai berikut:

a. Yang berhubungan dengan hak atas tanah, status hukumnya dikembalikan kepada hukum asal, siapa yang menghidupkan tanah yang mati dialah pemiliknya. Dalam al-Qur'an Surat al-Nisa' ayat 29 menegaskan "jangan saling memakan harta sesamu dengan jalan bathil (unjustly atau unlawfully), kecuali dengan perniagaan yang sah berdasarkan asas suka sama suka ('an tarāḍin atau in lawful)." ${ }^{26}$ Nabi Muhammad memberikan peringatan sangat keras dalam sabdanya: "barang siapa merampas tanah walaupun hanya seinci, Allah akan mengalungkan dilehernya api dari neraka kelak di hari kiamat (man iqtața-a shibran min al-ardi, țawwaqahu Allāh iyyāhu yauma-'l-qiyāmat min sab'i arāḍina).27 "Barang siapa mengambil harta milik umat Islam yang lain tanpa kebenaran (hak), akan mendapat kemurkaan Allah dan akan diadili di hadapanNya." (HR. Ahmad). Nabi Muhammad SAW memberi jaminan bahwa "barang siapa yang mati untuk membela harta miliknya maka ia mati syahid" (man qutila duna mālihi fahuwa syāhid). ${ }^{28}$ Penghormatan Islam terhadap hak milik pribadi dipertegas kembali oleh Rasulullah SAW dalam khotbah haji wadā'-nya: "sesungguhnya darahmu, dan hartamu adalah haram bagimu (untuk dilanggar)...."29

${ }^{26} \mathrm{QS}$, al-Baqarah: 188, bermakna sama.

${ }^{27}$ Imam Bukhari, Sahịh Bukhāry, jilid I.

${ }^{28}$ Muhammad Ibn Isma'il al-Shan'ani, Subūl al-Salām, jilid IV, (Kairo: Maktabah al-Mujallad al'Arabi, tt), h. 72.

${ }^{29}$ Ibid, juz III, h. 116. 
b. yang berhubungan dengan tidak adanya akses masyarakat untuk dapat menikmati hutan, maka perlu dirumuskan pengelolaan hutan yang mașlahat bagi semua pihak. Ukuran pengelolaan yang maslahah, dapat mengacu pada lima kriteria al-mașlahạ al-'āmmah yang dirumuskan Wahbah al-Zuhaili. Pertama, hutan dan pengelolaannya harus bermanfaat yang dapat dirasakan oleh seluruh atau sebagian besar masyarakat (baik MDH maupun Perhutani, c.q. negara). Kedua, selaras dengan tujuan syariah yang terangkum dalam al-kulliyyat al-khamsah, dalam konteks UU No. 41 tahun 1999 tentang Kehutanan sudah sesuai dengan asas-asasnya. Ketiga, manfaat yang dimaksud harus nyata (hakiki dan betul-betul dapat dirasakan) bukan sebatas perkiraan (wahmi) atau klaim sepihak saja. Keempat, tidak boleh bertentangan dengan al-Qur'an dan Hadits. Kelima, tidak boleh dilaksanakan dengan mengorbankan kepentingan umum lain yang sederajat apalagi yang lebih besar. ${ }^{30}$

\section{Paradigma Fiqh dalam Resolusi Sengketa Tanah}

Dari perspektif hukum Islam, ketika sengketa tanah telah terjadi ada dua jalur penyelesaian yang dapat ditempuh, yaitu hakam, ${ }^{31}$ dan ișlāh. ${ }^{32}$. Hakam dalam bentuknya yang paling konkret menjelma menjadi $q \bar{a} d \underline{i}$ (hakim) atau peradilan (qaḍ̄a / hukūmah) ${ }^{33}$ yang memutus perkara secara hukum. Sedangkan iṣlāḥ merupakan lembaga hukum yang mendamaikan, baik melalui pihak ketiga atau tidak. ${ }^{34}$

Berbeda dari pendapat di atas, ada pula yang menyatakan bahwa penyelesaian sengketa pada prinsipnya dapat menempuh tiga jalur, yaitu dengan cara damai (sulh), arbitrase (tahkim) dan terakhir melalui proses peradilan (al-qaḍā). Perbedaan dua pendapat di atas terletak pada konsep hakam, taḥkìm dan al-qaḍā'. Istilah hakam dan taḥkim terkadang dipahami dalam konteks penyelesaian sengketa secara damai dengan pihak ketiga sebagai

${ }^{30}$ Al-Zuhaili, Ușūl al-Fiqh al-Islāmiy, juz II, h. 1028. Sa'id Ramadhan al-Buthi, Dawābit al-Mașlahah fi al-Sharīah al-Islāmiyyah, (Beirut: Mu’assasah al-Risalah, 1986), h. 254. Abdul Wahhab al-Khallaf, Ilm Ușūl al-Fiqh, h. 86. Muhammad Abu Zahrah, Ușūl al-Fiqh, (Beirut: Dar al-Fikr, t.th.), h. 278.

${ }^{31}$ Antara lain QS. al-Nisa [4]: 105.

32 Antara lain QS. al-Nisa [4]: 128.

33 Muhammad Salam Madkur, Peradilan dalam Islam, (Surabaya: Bina Ilmu, 1993), h. 33.

34 Said Agil Husin al-Munawar, "Islah: Kajian Hukum Islam dan Hukum Positif," dalam Hukum Islam dan Pluralitas Sosial, (Jakarta: Penamadani, 2004), h. 60 dan seterusnya. 
penengah (arbitrator/mediator). Pengertian ini mirip dengan șulh, hanya beda pada kehadiran pihak ketiga. Tetapi apabila dilihat dari akar katanya, hakam dan tahkim juga dapat dipahami sebagai penyelesaian sengketa menurut hukum dengan al-qada' sebagai tempatnya. Ada pula yang berpendapat, di negara-negara Arab (modern-pen), penyelesaian sengketa nonlitigasi meliputi beberapa cara. Selain șulh (konsiliasi) dan taḥkìm atau ḥakam (arbitrase)—sebagaimana pada masa Nabi Muhammad SAW dan para sahabat-juga dikenal dengan istilah al-wasațah (mediasi). ${ }^{35}$

Sepanjang sejarah hukum Islam, dijumpai tiga model kekuasaan penegak hukum (lembaga penegak hukum), yaitu kekuasaan al-qaḍa' (wilāyāt al-qaḍa), kekuasaan al-hisbah (wilāyāt al-hisbah) dan kekuasaan al-madzalim (wilāyāt al-mazālim), yang masing-masing memiliki kewenangan berbeda. ${ }^{36}$ Al-Qaḍa' berwenang menyelesaikan masalah-masalah tertentu, mencakup perkara-perkara madāniyyāt, al-ahwwāl al-shakhsiyyah, jināyat dan tugas tambahan lain. Al-Hisbah merupakan lembaga resmi negara yang diberi kewenangan untuk menyelesaikan masalah-masalah ringan yang menurut sifatnya tidak memerlukan proses peradilan. Sedangkan al-mazālim merupakan badan pemerintah yang dibentuk khusus untuk membela orang-orang yang teraniaya akibat sikap semena-mena penguasa negara (yang lazim sulit diselesaikan oleh al-qaḍa' atau al-hisbah). Lembaga ini juga berwenang menyelesaikan persoalan suap atau korupsi.

Dalam prakteknya, hukum Islam tidak hanya menganjurkan berdamai untuk kasus-kasus perdata saja, bahkan damai dimungkinkan untuk masalah pidana. Rasulullah bersabda: "Barang siapa dengan sengaja membunuh, maka si pembunuh diserahkan kepada wali korbannya. Jika wali ingin melakukan pembalasan yang setimpal (qișās), mereka dapat membunuhnya. Jika mereka tidak ingin membunuhnya, mereka dapat mengambil diyat (denda) .... Dan apabila mereka berdamai, itu terserah kepada wali mereka." Batas-batas berdamai menurut Islam adalah perdamaian yang tidak menghalalkan yang haram dan mengharamkan yang halal. ${ }^{37}$

35 Salah al-Hejailan, 'Mediation as a Means for Amicable Settlement of Disputes in Arab Countries,' dalam Conference on Mediation, Geneva, 29 Maret 1996. Fathi Kemicha, The Approach to Mediation in the Arab World,' dalam Conference on Mediation, Geneva, 29 Maret 1996. Seperti dikutip Adi Sulistiyono, Mengembangkan ..., h. 338-9.

${ }^{36}$ Satria Effendi M. Zein, "Arbitrase dalam Islam", dalam Mimbar Hukum, No. 16, Tahun V, (Jakarta: Yayasan al-Hikmah, 1994), h. 51-2.

37 Ibid., h. 162. 
Spirit Islam menunjukkan bahwa hendaknya penyelesaian sengketa dilakukan dengan cara-cara di luar pengadilan, seperti implisit dijelaskan oleh Umar bin Khattab; "radd al-qaḍā' bayna dhawi al-arhām hatta yaștalihu fa inna fașla al-qad़ ā' yurithu al-ḍghain" (kembalikanlah penyelesaian perkara kepada sanak keluarga sehingga mereka dapat mengadakan perdamaian karenan sesungguhnya penyelesaian pengadilan itu dapat menimbulkan rasa tidak enak). ${ }^{38}$

Dukungan dari teks al-Qur'an maupun al-Hadits untuk menyelesaikan sengketa secara damai cukup banyak. Anjuran berdamai itu antara lain disebutkan dalam QS. al-Nisa' [4]: 128, 35, 129, al-Baqarah [2]: 182, 224, 228. Bahkan dalam konteks sengketa atau konflik yang telah mengeras menjadi perang terbuka pun, ajaran Islam tetap men-support untuk dilakukan perdamaian. Seperti dijelaskan dalam surat al-Anfal [8]: 61, "Dan apabila musuhmu condong pada perdamaian, engkau juga harus condong pada perdamaian... (wa in janaḥū li-'-salmi fa-jnaḥ lahā...). Jadi, perdamaian merupakan prinsip dasar dalam kehidupan (umat) Islam. Prinsip ini merupakan suatu jalan hidup yang memungkinkan seseorang atau masyarakat memecahkan dan mengatasi berbagai persoalan (termasuk persoalan di bidang tanah) dengan cara yang mudah, lancar, seimbang dan adil. ${ }^{39}$ Bahkan kata Islam sendiri-sebagai suatu nomenklatur agama-berarti agama yang damai.

Perdamaian dalam bentuk șuḷ untuk mengakhiri suatu persengketaan terbagi dalam tiga bentuk:40 pertama, perdamaian dalam suatu kasus yang sudah ada pengakuan pihak tergugat, yaitu seorang yang menggugat pihak lain tentang sesuatu objek gugatan dan pihak tergugat membenarkan isi tuntutan tergugat. Perdamaian demikian, menurut jumhur ulama dibolehkan. Kedua, perdamaian tentang sesuatu yang diingkari oleh pihak tergugat, seperti penggugat mempunyai hak atas sesuatu yang dikuasai oleh tergugat tetapi pihak tergugat menyangkal tuduhan tersebut. Menurut mazhab Malikiyyah, Hanafiyyah dan Hanabilah, perdamaian seperti demikian diperbolehkan. Alasannya karena keumuman ayat al-șulh khayr dan hadits Nabi

\footnotetext{
38 Muhammad Salam Madkur, Peradilan dalam Islam, h. 68.

${ }^{39}$ Afzalur Rahman, Nabi Muhammad sebagai Seorang Pemimpin Militer, (t.t.: Amzah, 2002), h. 12.

${ }^{40}$ Helmi Karim, Fiqh Muamalah, (Jakarta: Rajawali Press, 1993), h. 55-56.
} 
Muhammad SAW yang menganjurkan berdamai asal tidak menghalalkan yang haram dan mengharamkan yang halal; ketiga, perdamaian dalam kasus diamnya pihak tergugat, yakni adanya suatu perkara gugatan di mana pihak tergugat tidak memberikan jawaban atas gugatan yang dituduhkan kepadanya. Menurut Ibn Abi Laila, perdamaian dalam bentuk ini diperbolehkan. Namun mazhab Syafi'iyyah berpendapat bahwa perdamaian dalam bentuk ini tidak diperbolehkan karena sikap diam pihak tergugat adalah bentuk pengingkarannya.

\section{Resolusi Sengketa Tanah Kawasan Hutan Perspektif Fiqh}

Dalam pandangan hukum Islam, proses dan hasil merupakan dua hal yang sama-sama penting. Hukum suatu proses mempengaruhi dan berhubungan dengan hasil atau tujuan akhir. Tujuan yang baik harus diiringi dengan proses yang baik pula. Proses yang baik tidak akan mengabsahkan tujuan buruk. Dengan kata lain, tujuan akhir yang baik tidak akan menjadi baik kalau pelaksanaannya dilakukan dengan buruk. Dalam konteks penelitian ini, warga yang sedang memperjuangkan hak atas tanahnya meng-gunakan strategi penyelesaian sengketa yang bermacam-macam, seperti: (1) organisasi diri, (2) kerjasama dan menjalin komunikasi hukum, (3) aksi demonstrasi, (4) pembabatan pohon jati dan perlawanan menuntut balas. Strategi ini digunakan untuk mencapai resolusi yang diharapkan, dalam bentuk, (5) lobi dan negosiasi, dan (6) mediasi.

Penggunaan beragam strategi itu, sepanjang tidak melanggar prinsipprinsip hukum Islam diperbolehkan. Pelaksanaan strategi harus dilakukan dengan cara damai dan tidak menimbulkan kerusakan (madarat). Hanya pada point (4) pembabatan pohon jati dan perlawanan menuntut balas seharusnya dapat dihindari. Pembabatan berarti merusak, sesuatu yang sangat dilarang dalam Islam. ${ }^{41}$ Ayat ini mengandung makna larangan merusak bumi (atau apa saja, termasuk membabat pohon jati) setelah kondisinya baik (ișlāḥ). Makna ini menunjukkan bahwa manusia harus melindungi hal-hal yang sudah (tumbuh) baik. Jadi larangan merusak bumi juga berkaitan

\footnotetext{
${ }^{41}$ QS. al-'Araf [7]: 56.
} 
dengan usaha pelestarian lingkungan hidup, dan berusaha menciptakan sesuatu yang baru, yang baik (șālih) dan membawa kebaikan (mașlaḥah).

Negosiasi dan mediasi sebagai mekanisme penyelesaian sengketa tanah kawasan hutan oleh kedua belah pihak adalah merupakan bentuk mendahulukan penyelesaian secara kekeluargaan (di luar pengadilan) dari pada penyelesaian secara hukum (di pengadilan). Dua mekanisme ini juga sesuai prinsip damai. Penyelesaian secara kekeluargaan adalah penyelesaian di luar pengadilan dalam bentuk musyawarah mufakat atau negosiasi antar pihak yang bersengketa. Dapat pula mengangkat pihak ketiga (muhakkim/ arbirator) untuk ikut membantu menyelesaikan sengketa tanah. Dalam musyawarah-mufakat, negosiasi atau mediasi tersebut, masing-masing pihak dapat merumuskan kesepakatan yang saling menguntungkan dan tidak saling merugikan. Prinsip lebih mendahulukan penyelesaian secara kekeluargaan daripada penyelesaian melalui pengadilan.

Praktek musyawarah mufakat yang sangat didukung oleh ajaran Islam, seringkali tidak mudah dilakukan. Jangan musyawarah untuk mencapai kesepakatan, bertemu saja sangat susah. Kendalanya macam-macam, seperti pengingkaran adanya masalah antara keduanya, kendala psikologis dan arogansi perusahaan terhadap tuntutan $\mathrm{MDH}$, atau merasa pasti benar karena keberadaannya didukung oleh undang-undang. Oleh karenanya, MDH sebagai orang yang kecil dan kebanyakan tidak terdidik harus menggunakan beragam strategi untuk mengajak pihak Perhutani duduk bersama dan mengakui adanya masalah diantara kedua. Jika upaya mengajak duduk bersama ini berhasil, maka mekanisme negosiasi atau mediasi akan mudah dilakukan.

Strategi ini merupakan sesuatu yang tidak semuanya baru (seperti demonstrasi sudah pernah terjadai ketika terjadi kekacauan politik pada masa khulafa al-rasyidun), meskipun ada juga betul-betul baru. Strategi itu merupakan hal-hal yang sifatnya duniawi dan Nabi Muhammad SAW mempersilakan diterapkan. Jadi dalam konteks ini, strategi adalah țarīqah untuk menemukan jalan mașlaḥah, yaitu berdamai melalui negosiasi dan mediasi.

Hasil akhir dari negosiasi atau mediasi, berupa PMDH atau apaun namanya adalah implementasi dari kesepakatan damai. Perhutan dan MDH sepakat menyelesaikan masalahnya-terutama yang terkait dengan minim- 
nya akses masyarakat untuk menikmati hasil-hasil hutan-melalui kemitraan. Kemitraan ini disusun berdasarkan pada kemaslahatan bersama. Pengelolaan hutan dengan model seperti itu juga tidak pernah ada presedennya pada masa Nabi Muhammad SAW. Apabila kemaslahatan adalah tujuan akhir yang diinginkan oleh program PMDH, maka program demikian sesuai dengan spirit Islam. Sejauh yang dapat diamati, sebagian MDH memang merasakan dampak positif dari PMDH ini. Namun sebagian lain masih belum puas dan menuntut PMDH lebih banyak mengadopsi tuntutan-tuntutan dari masyarakat. PMDH pada akhirnya juga akan menjadi arena pertarungan kepentingan antara MDH dengan Perhutani. Mungkin saja timbul sengketa baru dari program ini, namun penyelesaian secara damai hendaknya lebih didorong pelaksanaannya.

\section{G. Kesimpulan}

Dari eksplorasi penulis di atas, dapat disimpulkan bahwa; pertama, sengketa tanah kawasan hutan yang terjadi di kabupaten Blora, disebabkan karena sebagai berikut: (a) masalah penebangan liar; (b) terjadi perselisihan antara masyarakat desa hutan (MDH) dan aparat KPH Randublatung; (c) kekerasan yang dilakukan oleh kedua belah pihak (MDH dan Perhutani; (d) klaim kepemilikan hak atas tanah. Resolusi sengketa yang ditawarkan oleh Perhutani: (a) pendekatan keamanan dan hukum; (b) kerja sama dengan MDH. Sedangkan resolusi yang dilakukan oleh MDH adalah dengan strategi dan mekanisme sebagai berikut: (a) mengorganisasi diri; (b) komunikasi dan kersama hukum dengan pihak lain; (c) aksi demonstrasi; (d) pembabatan dan perlawanan menuntut balas; (e) lobi dan negosiasi dan mediasi.

Kedua, negosiasi dan mediasi sebagai mekanisme penyelesaian sengketa tanah kawasan hutan oleh kedua belah pihak adalah merupakan bentuk mendahulukan penyelesaian secara kekeluargaan (di luar pengadilan) dari pada penyelesaian secara hukum (di pengadilan). Dua mekanisme ini juga sesuai prinsip damai sebagaiman tuntunan Islam. Terkait dengan penggunaan strategi seperti organisasi diri, komunikasi dan kerja sama dengan pihak aksi demonstrasi merupakan hal-hal yang sifatnya duniawi dan Nabi Muhammad SAW mempersilakan diterapkan. Jadi dalam konteks ini, strategi adalah tariqah untuk menemukan jalan maslahat, yaitu berdamai melalui negosiasi dan mediasi. Sedangkan pembabatan dan perlawanan menuntut balas 
bertentang dengan ajaran Islam. Hasil akhir dari negosiasi atau mediasi, berupa PMDH atau apaun namanya adalah implementasi dari kesepakatan damai. Perhutan dan MDH sepakat menyelesaikan masalahnya-terutama yang terkait dengan minimnya akses masyarakat untuk menikmati hasil-hasil hutan-melalui kemitraan. Kemitraan ini disusun berdasarkan pada kemaslahatan bersama. Pengelolaan hutan dengan model seperti itu juga tidak pernah ada presedennya pada masa Nabi Muhammad SAW. Apabila kemaslahatan adalah tujuan akhir yang diinginkan oleh program PMDH, maka program demikian sesuai dengan spirit Islam. Sejauh yang dapat diamati, sebagian MDH memang merasakan dampak positif dari PMDH ini. Namun sebagian lain masih belum puas dan menuntut PMDH lebih banyak mengadopsi tuntutan-tuntutan dari masyarakat. PMDH pada akhirnya juga akan menjadi arena pertarungan kepentingan antara MDH dengan Perhutani. Mungkin saja timbul sengketa baru dari program ini, namun penyelesaian secara damai hendaknya lebih didorong pelaksanaannya.[w] 


\section{BIBLIOGRAFI}

Baltaji, Muhammad, Metodologi Umar bin al-Khathab, Jakarta: Khalifa, 2005.

Berger, Peter L. dan Richard J. Neuhaus, To Empower People: The Role of Mediating Structures in Public Policy, Washington: American Institute for Public Policy Research, 1977.

Bukhari, Imam, Sahih Bukhari, jilid I.

al-Buthi, Sa'id Ramadhan, Dawābițal-Mașlahah fi al-Sharīah al-Islāmiyyah, Beirut: Mu'assasah al-Risalah, 1986.

De Graaf, H.J. dan TH. Pigeaud dalam buku Kerajaan Islam Pertama di Jawa: Tinjauan Sejarah Politik Abad XV dan XVI, Jakarta: Pustaka Utama Grafiti, 2001.

Effendi, Sofian dan Chris Manning, "Prinsip-prinsip Analisa Data" dalam Masri Singarimbun (ed.), Metode Penelitian Survei, edisi revisi, Jakarta: LP3ES, 1989.

Fuad, Faisal H., “Kajian Kasus Penjarahan Hutan di KPH. Randublatung,' dalam www.arupa.or.id. Akses tanggal 19 Agustus 2008.

al-Hejailan, Salah, 'Mediation as a Means for Amicable Settlement of Disputes in Arab Countries,' dalam Conference on Mediation, Geneva, 29 Maret 1996.

Karim, Helmi, Fiqh Muamalah, Jakarta: Rajawali Press, 1993.

Madkur, Muhammad Salam, Peradilan dalam Islam, Surabaya: Bina Ilmu, 1993.

Mangunwijaya, Fachruddin M., Konservasi Alam dalam Islam, (Jakarta: Yayasan Obor Indonesia, 2005.

Mary, Rahma, Dominasi dan Resistensi Pengelolaan Hutan di Jawa Tengah, Semarang: Huma dan LBH Semarang, 2007.

Muhadar, Viktimisasi Kejahatan di Bidang Pertanahan, Yogyakarta: Laksbang, 2006.

al-Munawar, Said Agil Husin, "Islah: Kajian Hukum Islam dan Hukum Positif" dalam Hukum Islam dan Pluralitas Sosial, Jakarta: Penamadani, 2004.

Prakosa, M., Rencana Kebijakan Kehutanan, Yogyakarta: Aditya Media, 1996. 
Rahman, Afzalur, Nabi Muhammad sebagai Seorang Pemimpin Militer, t.tp.: Amzah, 2002.

al-Shan'ani, Muhammad Ibn Isma'il, Subūl al-Salām, jilid IV, .Kairo: Maktabah alMujallad al-'Arabi, t.th.

Simon, H., Merencanakan Pembangunan Hutan untuk Strategi Kehutanan Sosial, Yogyakarta: Aditya Media, 1994.

Wawancara dengan Lukito, Koordinator Lidah Tani Blora, Juli 2008.

Wawancara dengan Siti Rahma MH, advokat di LBH Semarang, tanggal 20 Juli 2008.

Yin, Robert K, Studi Kasus: Desain dan Metode, Jakarta: Rajawalipers, 2004.

Zahrah, Muhammad Abu, Ushul al-Fiqh, Beirut: Dar al-Fikr, t.th.

Zein, Satria Effendi M., "Arbitrase dalam Islam", dalam Mimbar Hukum, No. 16, Tahun V, Jakarta: Yayasan al-Hikmah, 1994.

al-Zuhaili, Ushul al-Fiqh al-Islami, juz II.

\section{Internet dan Surat Kabar:}

http:// www.pemkabblora.go.id. diakses tanggal 19 Agustus 2008.

Suprapto, Edi, Konflik Kehutanan Yang Berbuah Kekerasan, dalam http:// www.arupa.or.id. diakses tanggal 20 Agustus 2008.

Winoto, Joyo, dalam Kompas, 2 Juni 2007.

Jawa Pos, 23 Mei 2007. 
